\title{
Krabbamein hjá börnum á Íslandi árin 1981-2006
}

\section{Trausti \\ Óskarsson \\ læknir ${ }^{1}$ \\ Ólafur Gísli \\ Jónsson \\ barnalæknir ${ }^{1,2}$}

Jón $\mathbf{R}$.

Kristinsson

barnalæknir ${ }^{1,2}$

\section{Guðmundur K. Jónmundsson}

barnalæknir ${ }^{1,2}$

\section{Jón Gunnlaugur}

Jónasson

meinafræðingur ${ }^{2,3,4}$

\section{Ásgeir \\ Haraldsson}

barnalæknir ${ }^{1,2}$

Lykiloro: börn, krabbamein, faraldsfræði, nýgengi.

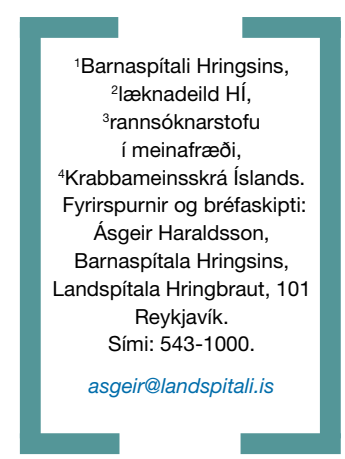

\section{Ágrip}

Inngangur: Krabbamein er næst algengasta dánarorsök barna á eftir slysum. Tilgangur rannsóknarinnar var að kanna nýgengi krabbameina hjá börnum á Íslandi.

Aðferðir: Rannsóknin var lýðgrunduð og náði til allra <18 ára sem greindust með krabbamein á Íslandi frá upphafi árs 1981 til ársloka 2006. Upplýsingum var safnað frá Krabbameinsskrá Íslands og úr sjúkraskrám.

Niðurstöður: Alls greindust288 krabbameinstilfelli á tímabilinu hjá 279 börnum. Í 10 tilvikum var um meðferðartengd krabbamein að ræða. Árlegt aldursstaðlað nýgengi hjá drengjum var 16,1 af 100.000 (95\% CI; 13,6-18,6) en hjá stúlkum 12,8 af 100.000 (95\% CI; 10,5-15,0) en ekki var marktækur munur á nýgengi milli fyrri og seinni hluta rannsóknartímabilsins. Fyrir aldursbilið 0-14 ára var árlegt aldursstaðlað nýgengi 13,6 af 100.000 . Miðtaugakerfisæxli og hvítblæði voru samanlagt $52,1 \%$ allra krabbameinstilvika. Algengasta greiningin var bráđa eitilfrumuhvítblæði $(17,9 \%)$ og stjarnfrumnaæxli $(13,1 \%)$ næstalgengust. Nýgengið var hæst hjá aldursbilunum 0-4 ára (17,3 af 100.00) og 15-17 ára (19,6 af 100.000). Tíu börn voru með pekkta meðfædda áhættupætti.

Ályktun: Nýgengi krabbameina hjá börnum á Íslandi er sambærilegt við nágrannalöndin. Mikilvægt er að fylgja vel eftir börnum sem gengið hafa í gegnum krabbameinsmeðferð og peim sem hafa pekkta meðfædda áhættupætti.

\section{Inngangur}

Krabbamein er algengasta sjúkdómstengda dánarorsökin hjá börnum og unglingum á Vesturlöndum..$^{1,2}$ Árlegt aldursstaðlað nýgengi er hins vegar aðeins um 13-17 af $100.000^{2-6}$ og hefur pað lítið breyst á síðustu áratugum.?

Mikill munur er á krabbameinum hjá börnum og fullorðnum. Krabbamein greinast mun sjaldnar hjá börnum, pau eru oftar á hærri stigum við greiningu en horfur eru almennt betri en hjá fullorðnum. Að auki greinast börn gjarnan með aðrar krabbameinstegundir. Fullorðnir greinast oftast með pekjufrumuæxli en hjá börnum eru bráðahvítblæði og æxli í miðtaugakerfi orsök rúmlega helmings allra krabbameinstilvika. ${ }^{2}$ Margar tegundir krabbameina er nær eingöngu að finna hjá börnum, eins og til dæmis nýrnakímfrumnaæxli (nephroblastoma, Wilms æxli), taugakímfrumnaæxli (neuroblastoma) og sjónkímfrumnaæxli (retinoblastoma). ${ }^{8}$

Orsakir krabbameina hjá börnum eru að mestu ópekktar og oftast af öðrum toga en hjá fullorðnum par sem ákveðnir lífsstílstengdir áhættupættir eru vel pekktir eins og reykingar, alkóhól og ákveðið mataræði. Pekktir eru meðfæddir sjúkdómar og heilkenni sem auka hættuna á krabbameinsmyndun hjá börnum en peir eru sjaldgæfir. Dæmi um pá eru taugatrefjaæxlager (neurofibromatosis), Downs heilkenni, tuberous sclerosis, Li-Fraumeni heilkenni og Fanconi blóðleysi. ${ }^{8}$ Hins vegar er vel pekkt að börn sem fengið hafa krabbameinsmeðferð eru í aukinni hættu á að greinast aftur síðar á lífsleiðinni með krabbamein sem oft má rekja til krabbameinslyfja- eða geislameðferðarinnar. Geta meðferðartengd krabbamein greinst allt að 20 árum eftir meðferð. ${ }^{9,} 10$ Ýmis önnur vandamál kunna að fylgja krabbameinsmeðferð eins og vanstarfsemi í skjaldkirtli og heiladingli, truflun á vexti og proska, heyrnartap og skerðing á starfsemi hjarta og nýrna. ${ }^{11,}{ }^{12}$ Í eftirfylgd er pví mjög mikilvægt að skima fyrir langvinnum fylgikvillum krabbameinsmeðferðar.

Líkt og hjá fullorðnum hafa öll krabbameinstilfelli sem greinst hafa hjá börnum verið skráð hjá Krabbameinsskrá Íslands frá árinu 1954. Par er skráð staðsetning frumæxlis og ICD-10 (International Classification of Disease, 10.útgáfa) greining auk einfaldra bakgrunnsupplýsinga. ICCC-3 flokkunarkerfið (International Classification of Childhood Cancer, 3. útgáfa) ${ }^{13}$ var hannað með krabbamein í börnum og unglingum í huga og eru krabbamein flokkuð eftir vefjagerð frekar en staðsetningu eins og í ICD-10 flokkunarkerfinu. Hentar pað kerfi mun betur við rannsóknir á krabbameinum í börnum og í samanburði milli landa.

Rannsókn par sem nýgengi krabbameina hjá börnum á Íslandi er kannað hefur ekki verið birt áður. Afar mikilvægt er að upplýsingar um faraldsfræði krabbameina séu áreiðanlegar og sem nákvæmastar. Auðveldar pað samanburð og áætlanir um pjónustu fyrir pennan sjúklingahóp, par með talið markvisst eftirlit.

Tilgangur pessarar rannsóknar var að kanna 


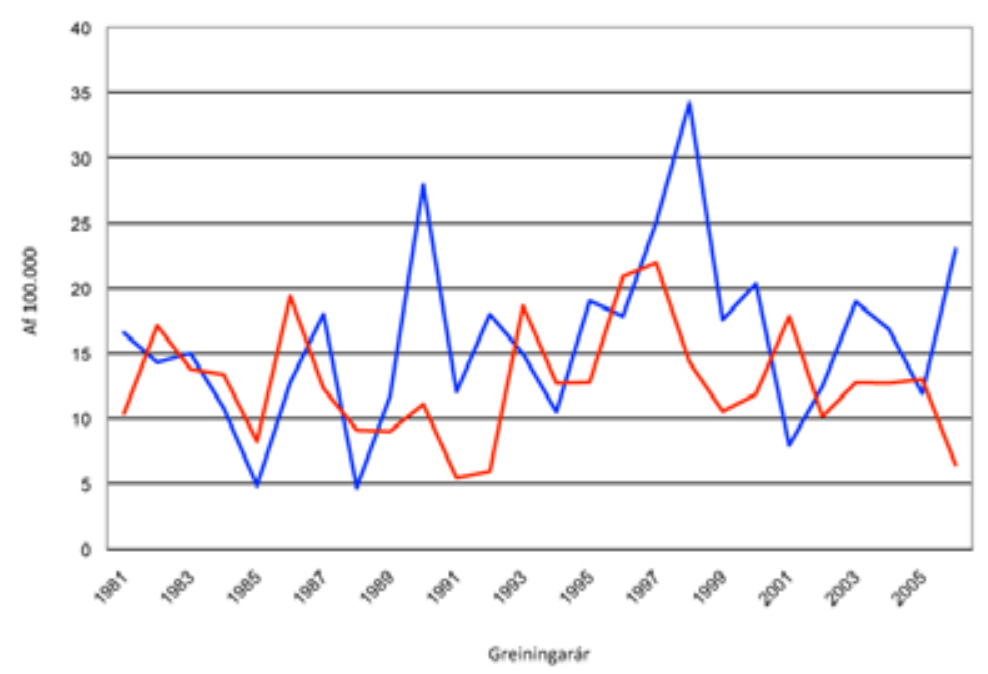

Mynd 1. Aldursstaðlað nýgengi illkynja sjúkdóma hjá börnum (miðað við 100.000 börn <18 ára) eftir greiningarárum. Bláa línan = drengir, rauða línan = stúlkur.

\section{Aðferðir}

Rannsóknin var afturskyggn og lýðgrunduð. Hannaður var gagnagrunnur (File Maker Pro 8.0) og í hann skráð öll krabbameinstilfelli sem greind hafa verið hjá einstaklingum yngri en 18 ára og tilkynnt hafa verið til Krabbameinsskrár Íslands frá 1.1.1981-31.12.2006. Nánari upplýsingar voru fengnar úr sjúkraskrám Landspítala, Barnaspítala Hringsins, og Sjúkrahússins á Akureyri. Hvert tilvik var yfirfarið með tilliti til greiningar, greiningardagsetningar, búsetu við greiningu og endurkomu sjúkdóms.

Upplýsingar sem skráðar voru í gagna-

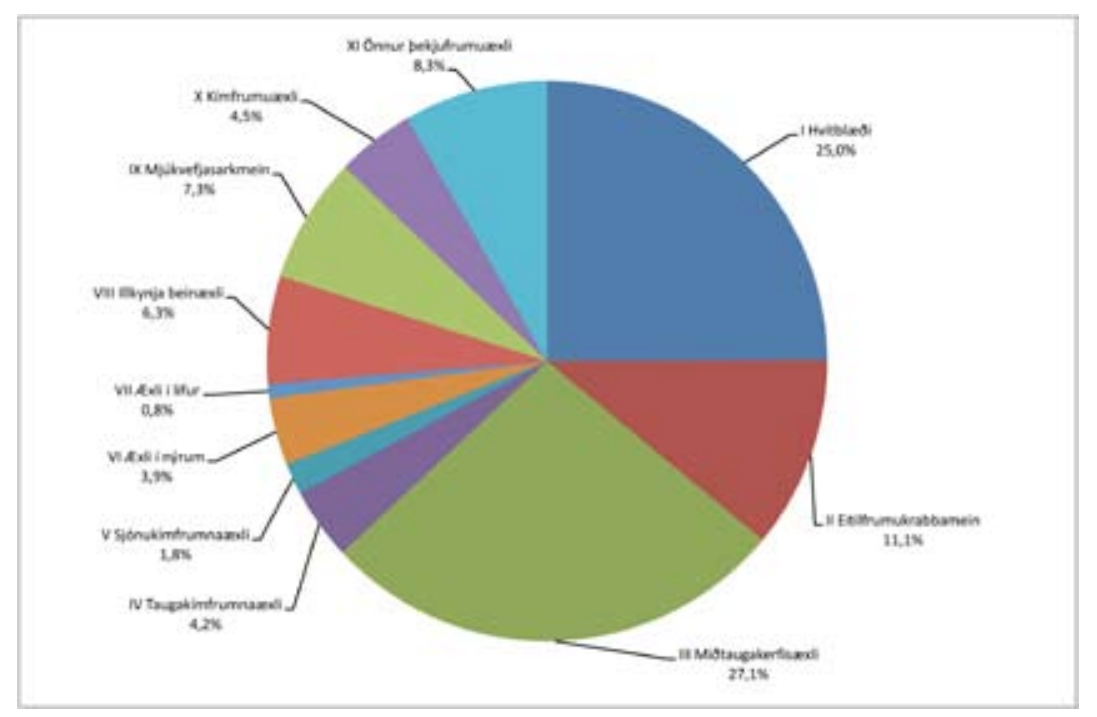

Mynd 2. Hlutfallsleg skipting allra krabbameinstilfella á rannsóknartímabilinu eftir aðalflokkum ICCC-3. grunninn voru eftirfarandi: Aldur, kyn, pekktir undirliggjandi áhættupættir, búseta við greiningu, aldur við greiningu, greining og undirflokkun. Ef einstaklingur greindist síðar með aðra tegund af krabbameini flokkaðist pað sem nýtt sjúkdómstilfelli í gagnagrunninn.

Áhættupáttur var skilgreindur sem pekktur erfðafræðilegur breytileiki sem eykur hættu á illkynja sjúkdómum og sem vitað var um áður en krabbameinið greindist.

Öll illkynja krabbamein voru skráð í gagnagrunninn og að auki öll góðkynja æxli í miðtaugakerfi. Hins vegar voru góðkynja æxli í kynkirtlum og beinum og traffrumnager (Langerhans cell histiocytosis) ekki skráð líkt og hefð er fyrir hjá Krabbameinsskrá Íslands. Pannig voru 24 manns sem eru í Krabbameinsskrá Íslands útilokaðir frá rannsókninni.

Krabbamein voru flokkuð útfrá ICCC-3 flokkunarkerfinu, 12 aðalflokkum og undirflokkum pegar pað átti við. ${ }^{13}$ Alheimsaldursstöðlun var notuð við nýgengisútreikninga ${ }^{14}$ og miðað við tilvik af 100.000 börnum <18 ára. Aldursstöðlun var gerð með tilliti til aldursbilanna 0-4 ára, 5-9 ára, 10-14 ára og 15-17 ára. Upplýsingar um fjölda barna á Íslandi fengust hjá Hagstofu Íslands. Útreikningar á nýgengi og öryggismörkum (confidence interval, CI) voru gerðir í Excel. Öryggismörk fyrir marktækni miðuðust við 95\%.

Fengið var leyfi frá lækningaforstjóra Landspítala, Persónuvernd (tilvísunarnúmer: 2007100755), siðanefnd Landspítala, vísindasiðanefnd heilbrigðisráðuneytisins (tilvísunarnúmer: VSNb2008090009) og yfirlækni Krabbameinsskrár Íslands.

\section{Niðurstöður}

Á rannsóknartímabilinu greindust 288 tilvik af krabbameinum hjá börnum á Íslandi. Af peim voru 278 frumtilvik og 10 meðferðartengd tilvik hjá níu börnum. Hjá einum einstaklingi greindust alls prjú tilvik. Alls voru pví 279 börn greind með krabbamein á tímabilinu. Árlegt aldursstaðlað nýgengi fyrir rannsóknartímabilið í heild var 14,5 af 100.000 börnum < 18 ára. Fyrir aldursbilið 0-14 ára var nýgengið 13,6 af 100.000 en fyrir aldursbilið 15-17 ára var nýgengið 19,6 af 100.000. Á mynd 1 má sjá breytingar á nýgengi eftir kynjum á rannsóknartímabilinu. Ekki var marktæk breyting á nýgengi pegar greiningarárunum var skipt upp í tvö tímabil 1981-1993 og 1994-2006. Á árunum 1981-1993 greindust 71 drengir, nýgengi 14,0 af 100.000 (95\% CI; 10,7-17,3) en á árunum 19942006 greindust 94 drengir, nýgengi 18,2 af 100.000 (95\% CI; 14,5-21,9). Á ofangreindum tímabilum 
greindust 55 stúlkur á fyrra tímabilinu, nýgengi 11,9 af 100.000 (95\% CI; 8,7-15,0) og 68 á síðara tímabilinu, nýgengi 13,7 af 100.000 (95\% CI; 10,416,9). Heildarnýgengi krabbameina hjá drengjum var 16,1 af 100.000 (95\% CI; 13,6-18,6) og hjá stúlkum 12,8 af 100.000 (95\% CI; 10,5-15,0) en munurinn reyndist ekki marktækur.

Æxli í miðtaugakerfi (78 tilvik) og hvítblæði (72 tilvik) voru algengustu krabbameinstegundirnar, samtals 150 tilvik af 288 eða 52,1\% tilvika (mynd 2). Bráðaeitilfrumuhvítblæði var algengasta hvítblæðistegundin, 58 af 72 tilvikum, en síðan kom bráðamergfrumuhvítblæði, 12 af 72 . Í premur tilvikum að auki var ekki hægt að flokka á milli bráðaeitilfrumu- og mergfrumuhvítblæðis. Prjú tilvik af langvinnu hvítblæði greindust og tvö af myelodysplastic syndrome (MDS). Eitilfrumukrabbameinin (32 tilvik) skiptust nokkuð jafnt á milli Hodgkins og Non-Hodgkins gerða, 18 af 32 og 14 af 32. Æxli í miðtaugakerfi greindust hjá 78 einstaklingum og af peim voru stjarnfrumnaæxli (astrocytoma) algengust 38 af 78 . Níu af 78 æxlum í miðtaugakerfi voru í undirflokknum Intracranial and intraspinal embryonal tumors en af peim voru sex primitive neuroectodermal tumor (PNET) og prjú mænukímfrumnaæxli (medulloblastoma). Tólf tilvik greindust af taugakímfrumnaæxlum, fimm sjónukímfrumnaæxli og 11 æxli í nýrum, öll nýrnakímfrumnaæxli. Tvö tilvik greindust af lifrarkrabbameini, eitt lifrarpekjuvefsæxli (hepatocellular carcinoma) og annað lifrarkímfrumnaæxli (hepatoblastoma). Af 18 tilvikum með illkynja krabbamein í beinum voru 13 með beinsarkmein (osteosarcoma) og fimm með Ewing's sarkmein. Mjúkvefjasarkmein greindust í 21 tilviki, 13 með rákvöðvasarkmein (rhabdomyosarcoma) og af peim voru níu af embryonal gerð, tvö af alveolar gerð en í tveimur tilvikum var ekki greint á milli embryonal og alveolar gerðar. Prettán tilvik greindust af kímfrumuæxlum (germ-cell neoplasms) og 24 af pekjufrumuæxlum. Ekkert tilvik greindist i ICCC3 flokki XII „Other and unspecified malignant neoplasms".

Góðkynja æxli í kynkirtlum og beinum voru 24 talsins og voru undanskilin frá rannsókninni. Að auki voru tvö meðferðartengd MDS tilvik ekki tilkynnt til Krabbameinsskrár Íslands. Almennt var samræmi milli Krabbameinsskrár Íslands og sjúkraskráa sjúkrahúsanna mjög gott.

Á mynd 3 má sjá nýgengi krabbameina eftir ICCC-3 flokkum og kynjaskiptingu peirra. Par sést að drengir greinast marktækt oftar með eitilfrumukrabbamein en stúlkur. Nýgengi eitilfrumukrabbameina hjá drengjum var 2,5 af 100.000 (95\% CI; 1,5-3,4) en hjá stúlkum var

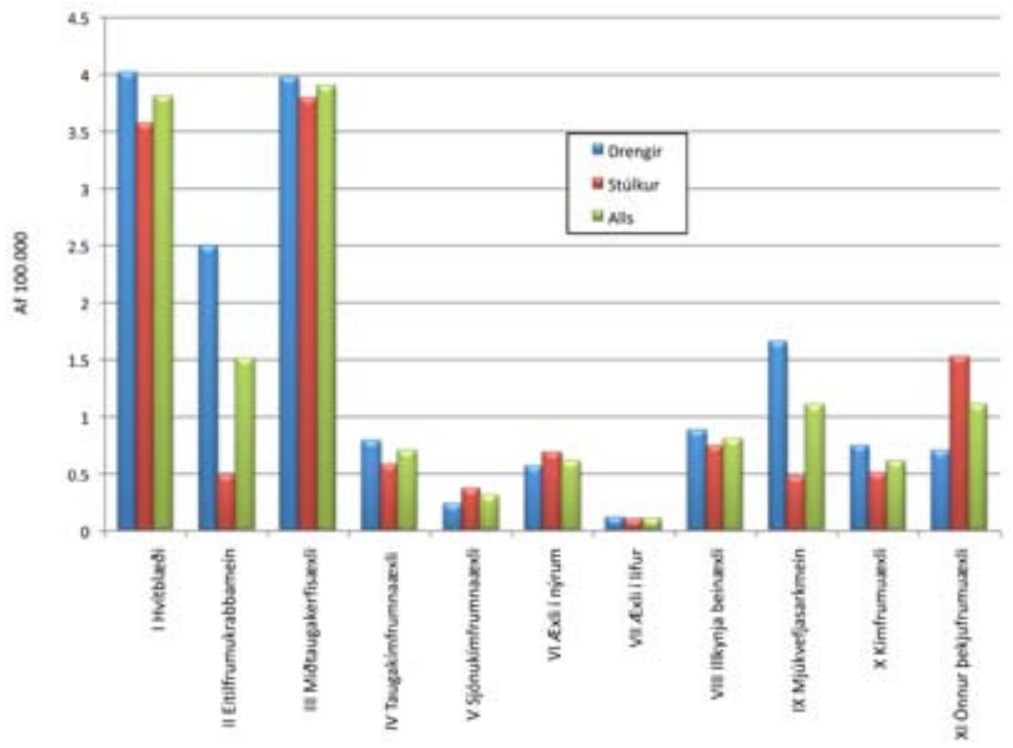

nýgengið 0,5 af 100.000 (95\% CI; 0,1-0,9). Ekki var marktækur munur á milli kynja hjá öðrum krabbameinstegundum.

Krabbamein voru algengust á aldrinum 1-2 ára og 16-17 ára. Nýgengið í aldurshópnum 0-4 ára var 17,3 af 100.000 (95\% CI; 13,8-20,7), 5-9 ára 10,2 af 100.000 (95\% CI; 7,6-12,9), 10-14 ára 12,4 af 100.000 (95\% CI; 9,5-15,4) og 15-17 ára 19,6 af 100.000 (95\% CI; 14,8-24,3). Yngstu börnin voru með hæsta nýgengið af hvítblæði, taugakímfrumnaæxlum, sjónukímfrumnaæxlum og nýrnaæxlum. Hins vegar var nýgengi eitilfrumukrabbameina, illkynja krabbameina í beinum, kímfrumuæxla og pekjufrumukrabbameina hæst hjá unglingunum (mynd 4).

Nýgengi var flokkað eftir búsetu við greiningu. Vegna smæðar pýðisins reyndist ekki mögulegt

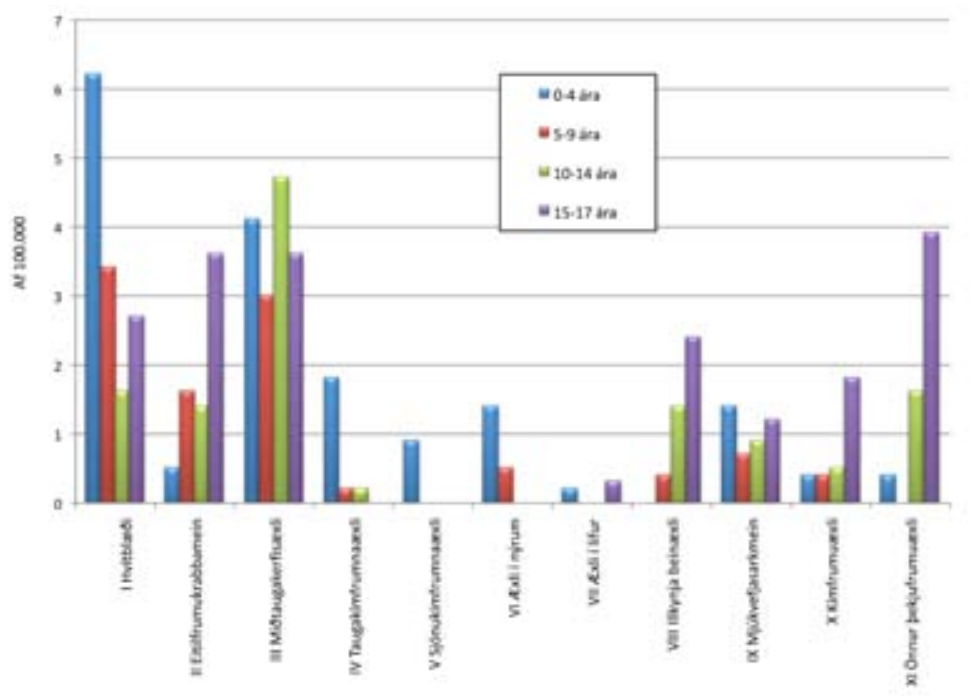

Mynd 4. Aldursstaðlað nýgengi illkynja sjúkdóma hjá börnum (miðað við 100.000 börn <18 ára) eftir aldurshópum, 0-4 ára, 5-9 ára, 10-14 ára og 15-17 ára.
Mynd 3. Aldursstaðlað nýgengi illkynja sjúkdóma hjá börnum (miðað við 100.000 börn <18 ára) i heild og eftir kynjum samkvæmt aðalflokkum ICCC-3. 
að bera saman nýgengi milli sýslna, kjördæma eða minni eininga. Borið var saman nýgengi milli höfuðborgarsvæðisins (14,3 af 100.000) og landsbyggðarinnar (14,6 af 100.000) og reyndist sá munur ekki marktækur.

Tíu meðferðartengd tilvik greindust á rannsóknartímabilinu. Tvö af peim voru bráðamergfrumuhvítblæði, tvö MDS, tvö stjarnfrumnaæxli af gráđu 4 (glioblastoma multiforme), tvö beinsarkmein, eitt sarkmein í mjúkvef og eitt bráđahvítablæði af óskilgreindum uppruna. Tvö af meðferðartengdu tilvikunum greindust hjá sama einstaklingnum, MDS og síðar bráðamergfrumuhvítblæði.

Að meðferðartengdu tilvikunum frádregnum voru 10 börn með pekkta áhættupætti fyrir krabbameinum, sex með taugatrefjaæxlager, tvö með Downs-heilkenni og tvær stúlkur með XY-litningagerð og pure gonadal dysgenesis. Börnin með Downs-heilkenni greindust með bráða eitilfrumuhvítblæði og bráða mergfrumuhvítblæði en stúlkurnar með XY litningagerðina greindust báðar með kynkirtilskímfrumnaæxli (gonadoblastoma) í eggjastokkum með illkynja frumubreytingum. Af peim sex sem voru með taugatrefjaæxlager voru tvö með sjóntaugaræxli (optic glioma) og önnur æxli í heilavef (other glioma), eitt með sjóntaugaræxli og stjarnfrumnaæxli, eitt með æxli í heilavef, eitt með stjarnfrumnaæxli og eitt með aftanskinu taugatrefjasarkmein (retroperitoneal neurofibrosarcoma).

\section{Umræða}

Í pessari rannsókn var leitast við að varpa ljósi á nýgengi krabbameina hjá börnum á Íslandi. Er petta fyrsta rannsóknin sem birtist hér á landi um petta efni.

Aldursstaðlað nýgengi krabbameina hjá börnum á Íslandi á rannsóknartímabilinu var 14,5 af 100.000 börnum <18 ára og hefur pað haldist nokkuð óbreytt frá árinu 1981. Í sjaldgæfum sjúkdómum eins og krabbameinum hjá börnum geta verið miklar tilviljanasveiflur á nýgengi milli ára. Sérstaklega á pað við pegar pýðið er fámennt eins og á Íslandi. Pví ber að taka með varúo breytileika í nýgengistölum milli ára. Langt rannsóknartímabil eins og í pessari rannsókn minnkar pó áhrif tilviljana á nýgengisútreikninga.

Erlendis er hefð fyrir pví að skilgreina krabbamein á aldursbilinu 0-14 ára sem krabbamein hjá börnum (childhood cancer) en krabbamein á aldursbilinu 15-19 ára sem krabbamein hjá unglingum (adolescent cancer). Í okkar rannsókn var hins vegar miðað við aldursbilið 0-18 ára sem er sá aldurshópur sem meðhöndlaður er af barnalæknum á Íslandi, oftast á Barnaspítala Hringsins og í norrænu samstarfi. Ef heildarnýgengi krabbameina hjá börnum 0-14 ára á Íslandi (13,6 af 100.000) er borið saman við nágrannapjóðirnar er pað sambærilegt við niðurstöður frá Evrópu (13,1 af 100.000) og Bandaríkjunum (15,3 af 100.000). ${ }^{2}$

Rannsókn pessi var lýðgrunduð og að auki voru allar sjúkraskrár sjúklinga yfirfarnar. Af peim sökum eru faraldsfræðilegu upplýsingarnar mjög áreiðanlegar í rannsókninni og að öllum líkindum nákvæmari en upplýsingar í rannsóknum um faraldsfræði krabbameina í börnum hjá nágrannapjóðum okkar. Árið 1981 hófu Norðurlöndin samstarf um flokkun, skráningu og meðferð krabbameina hjá börnum með stofnun Nordic Society of Pediatric Hematology and Oncology (NOPHO). Hefur pessi samvinna meðal annars auðveldað rannsóknir á árangri meðferðar og samanburð á milli Norðurlandanna. Pær upplýsingar sem sendar hafa verið til NOPHO hafa verið í höndum barnalækna Landspítala pannig að börn með staðbundin sortuæxli sem fjarlægð voru utan spítala og unglingar sem meðhöndlaðir voru á fullorðinsdeildum í upphafi rannsóknartímabilsins voru ekki öll tilkynnt til NOPHO. Á undanförnum árum hafa langflest krabbameinstilvik hjá börnum sem purfa meðferð komið til meðhöndlunar á Barnaspítala Hringsins.

Krabbameinsskrá Íslands skráir öll illkynja mein auk góðkynja meina í miðtaugakerfi og góðkynja mein í kynkirtlum og beinum. Flokkunarkerfi ICCC-3 tekur ekki með góðkynja æxli í kynkirtlum og beinum. Alls voru pví 24 tilvik undanskilin frá rannsókninni með slík mein. Að auki voru tvö meðferðartengd MDS tilvik ekki tilkynnt til Krabbameinsskrár Íslands en MDS er sjúkdómshópur sem krabbameinsskrár hafa átt erfitt með að afla upplýsinga um og henda reiður á.

Ekki reyndist vera marktækur munur á nýgengi drengja og stúlkna. Prátt fyrir pað er vel pekkt að drengir eru almennt í meiri hættu á að fá krabbamein heldur en stúlkur." 15 Áhugavert var hversu mikið oftar drengir fá eitilfrumukrabbamein en stúlkur. Ástæður pess að drengir greinast oftar með krabbamein en stúlkur eru ópekktar.

Eins og búist var við var aldursdreifing krabbameina í bernsku sú sama og sýnt hefur verið fram á í erlendum rannsóknum. Algengust eru pau hjá börnum 1-2 ára og 16-17 ára. Yngstu börnin fá fyrst og fremst hvítblæði og æxli upprunnin frá óproskuðum forstigsfrumum sem 
eru nokkuð sértæk fyrir pann aldurshóp eins og sjónuhimnukímfrumnaæxli, taugakímfrumnaæxli og mænukímfrumnaæxli. Athyglisvert er að um helmingur barna undir 15 ára sem greinist með krabbamein greinist fyrir 5 ára aldur ${ }^{16,17}$ og var pað einnig raunin í okkar rannsókn. Mögulega endurspeglar pað aukna virkni og fjölgun óproskaðra forstigsfrumna á pessu aldursskeiði.

Algengustu krabbameinstegundirnar hjá unglingum reyndust vera eitilfrumukrabbamein, illkynja beinæxli, pekjufrumuæxli og ýmis kímfrumuæxli. Á unglingsaldri verður vöxtur beina og kynkirtla mikill og er aukning á krabbameinum í peim vefjum í samræmi við aukna umsetningu frumna á pessu tímabili ævinnar. Pekjufrumuæxli eins og æxli í skjaldkirtli og pekjufrumuæxli í hálsi og koki verða einnig algengari á unglingsaldri en nýgengi pekjufrumuæxla almennt eykst eftir pví sem líða tekur á fullorðinsárin, til dæmis lungna-, ristil- og brjóstakrabbamein.?

Áhugavert var að kanna nýgengi eftir búsetu við greiningu. Eins og áður segir hafa sprottið upp í gegnum tíðina umræður um tengsl búsetu við nýgengi krabbameins. Pekkt eru tilvik par sem börn af sama kyni og aldri búsett í fámennri byggð hafi greinst með sjaldgæf krabbamein með stuttu millibili. Ekki hefur tekist að sýna fram á beint orsakasamband en líklegast er að um tilviljun sé að ræða. Vegna smæðar pýðis reyndist einungis hægt að bera saman nýgengi milli höfuðborgarsvæðisins og landsbyggðarinnar og var ekki marktækur munur par á milli.

Par sem krabbamein hjá börnum eru sjaldgæf og af ólíkum uppruna hefur reynst erfitt að finna sterk tengsl við ákveðna umhverfispætti. Hins vegar eru pekkt tengsl við ákveðna erfðasjúkdóma og meðfædd heilkenni og sér í lagi eru tengslin sterk ef einstaklingur hefur áður greinst með krabbamein og fengið krabbameinsmeðferð. ${ }^{18}$

Tíu börn sem greindust á rannsóknartímabilinu voru með pekkta meðfædda áhættupætti, taugatrefjaæxlager, Downs-heilkenni og stúlkur með XY litningagerð. Börn með taugatrefjaæxlager eru í aukinni hættu á að fá sjóntaugaæxli og önnur góðkynja æxli í heilavef en hluti af peim fær stjarnfrumnaæxli sem oftast eru af lágri gráðu. ${ }^{19}$ Í Downs-heilkenni er 10-20-föld hætta bæði á bráđaeitilfrumuhvítblæði og bráðamergfrumuhvítblæði ${ }^{20}$ og hjá stúlkum með XY litningagerð sem greinast með pure gonadal dysgenesis er oftast mælt með brottnámi eggjastokka vegna hættunnar á illkynja meinum í eggjastokkum. ${ }^{21}$ Mikilvægt er pví að vera vakandi fyrir krabbameinum hjá peim sem hafa pekkta meðfædda áhættupætti.

Eftirfylgd peirra sem fengið hafa krabbameinsmeðferð í æsku er mjög mikilvæg. Ýmsir síðkomnir fylgikvillar geta komið fram jafnvel mörgum árum eftir að meðferð lýkur. Talið er að um $10 \%$ hópsins fái síðar krabbamein sem rekja má til meðferðarinnar í æsku. ${ }^{9,} 22$ Níu greindust með meðferðartengd krabbamein á rannsóknartímabilinu, par af einn með tvö meðferðartengd tilvik. Helstu orsakir meðferðartengdra krabbameina eru fyrri geislameðferð og krabbameinslyf af flokki alkýlerandi lyfja og tópóísómerasa hemja. Að auki er hluti pessara einstaklinga líklega með aukna erfðafræðilega hættu á krabbameinsmyndun. Hér á landi er börnum sem gengið hafa í gegnum krabbameinsmeðferð fylgt eftir af barnalæknum Barnaspítala Hringsins reglulega fram á fullorðinsár. Með reglulegu sérhæfðu eftirliti er hægt að minnka líkur á alvarlegum síðkomnum fylgikvillum og bæta lífsgæði.

Rannsókn okkar varpar ljósi á nýgengi krabbameina hjá börnum á Íslandi og auðveldar samanburð við erlendar rannsóknir. Að auki ætti hún að koma að gagni við áætlanir og skipulag pjónustu fyrir pessa einstaklinga.

\section{Pakkir}

Lárus Guðmundsson kerfisfræðingur og Kristleifur Kristjánsson læknir hjá Íslenskri erfðagreiningu fá pakkir fyrir aðstoð við hönnun gagnagrunnsins, Elínborg Ólafsdóttir verkfræðingur hjá Krabbameinsskrá Íslands fyrir tölfræðiaðstoð. Rannsóknin hlaut styrk úr Kristínarsjóði árið 2008.

\section{Heimildir}

1. Jemal A, Siegel R, Ward E, et.al. Cancer statistics, 2006. CA Cancer j Clin 2006; 56: 106-30.

2. Ries LAG, Eisner MP, Kosary CL, et.al. Cancer Statistics Review, 1975-2002, SEER National Cancer Institute. http:// seercancergov/csr/1975_2002. 2005.

3. ACCIS. National estimates of incidence rates standardized to world standard population age 0-14 and 0-19. Automated Childhood Cancer Information System. 2003.

4. G. Gustafsson MH, A. Vernby. Childhood Cancer Incidence and Survival in Sweden 1984-2005. Report 2007 from the Swedish Childhood Cancer Registry. 2007.

5. Li J, Thompson TD, Miller JW, Pollack LA, Stewart SL. Cancer incidence among children and adolescents in the United States, 2001-2003. Pediatrics 2008; 121: 1470-7.

6. NOPHO. Childhood cancer in the Nordic Countries. 2008.

7. Jónasson JG, Tryggvadóttir Le. Krabbamein á Íslandi Upplýsingar úr Krabbameinsskrá fyrir tímabilið 1957-2006. Krabbameinsfélagið. 2008

8. Lanzkowsky P. Manual of Pediatric Hematology and Oncology. 4 útg. 2005.

9. Inskip PD, Curtis RE. New malignancies following childhood cancer in the United States, 1973-2002. Int J Cancer 2007; 121: 2233-40.

10. Olsen JH, Moller $\mathrm{T}$, Anderson $\mathrm{H}$, et al. Lifelong Cancer Incidence in 47697 Patients Treated for Childhood Cancer in the Nordic Countries. J Natl Cancer Inst 2009; 101: 806-13.

11. Hólm H, Jónsson ÓG, Pórsson ÁV, et al. Greining, árangur meðferðar og síðkomnar aukaverkanir æxla í miðtaugakerfi í æsku. Læknablaðið 2002; 88: 21-7. 
12. Kristinsson VH, Kristinsson JR, Jónmundsson GK, Jónsson ÓG, Pórsson ÁV, Haraldsson Á. Síðkomnar og langvinnar aukaverkanir eftir hvítblæðismeðferð í æsku. Læknablaðið 2002; 88: 13-8.

13. Steliarova-Foucher E, Stiller C, Lacour B, P K. International Classification of Childhood Cancer, third edition. Cancer 2005; 103: 1457-67.

14. Segi M. Cancer Mortality for Selected Sites in 24 Countries (1950-1957). Sendai, Japan: Tohoku University School of Medicine. 1960

15. National Cancer Institude (NCI) - Surveillance E, and End Results (SEER). SEER pediatric monograph 1975-1995. 1999.

16. Pritchard-Jones K, Kaatsch P, Steliarova-Foucher E, Stille CA, Coebergh JWW. Cancer in children and adolescents in Europe: Developments over 20 years and future challenges. Eur J Cancer 2006; 42: 2183-90.

17. Miller RW, Young JL, Jr., Novakovic B. Childhood cancer 1995; Cancer 75(1 Suppl): 395-405.
18. Bhatia S, Sklar C. Second cancers in survivors of childhood cancer. Nature Rev Cancer 2002; 2: 124-32.

19. Rodriguez FJ, Perry A, Gutmann DH, et al. Gliomas in neurofibromatosis type 1: a clinicopathologic study of 100 patients. J Neuropathol Exp Neurol 2008; 67: 240-9.

20. Hasle H. Pattern of malignant disorders in individuals with Down's syndrome. Lancet Oncology 2001; 7: 429-36.

21. Gourlay WA, Johnson HW, Pantzar JT, McGillivray B, Crawford R, Nielsen WR. Gonadal tumors in disorders of sexual differentiation. Urology 1994; 43: 537-40.

22. MacArthur AC, Spinelli JJ, Rogers PC, Goddard KJ, Phillips $\mathrm{N}$, McBride ML. Risk of a second malignant neoplasm among 5 -year survivors of cancer in childhood and adolescence in British Columbia, Canada. Pediatr Blood Cancer 2007; 48: 453-9.

\section{Childhood cancer in Iceland 1981-2006}

Background: Childhood cancer is the second most common cause of death in children. The aim of this study was to gather epidemiological information on childhood cancer in Iceland.

Methods: The study was population based and included all children younger than 18 years of age, diagnosed with cancer in Iceland from 1981 to 2006. Information was extracted from the Icelandic Cancer Registry and patient hospital records.

Results: During the study period 288 cancer cases were diagnosed in 279 children, 10 cases were secondary neoplasms. Age standardized incidence was 16.1 per $100.000(95 \% \mathrm{Cl} 13,6-18,6)$ for boys and 12.8 per 100.000
$(95 \% \mathrm{Cl} 10,5-15,0)$ for girls. There was no significant difference in the incidence rate between the first and second half of the study period. For children aged 0 14 years, the age standardized incidence was 13.6 per 100.000. The incidence was highest in the $0-4$ year age group (17.3 per 100.000) and in the 15-17 year age group (19.6 per 100.000). Brain tumors (27.1\%) and leukemia (25.0\%) were the most common cancer groups diagnosed. Lymphoid leukemia was the most common cancer type (17.9\%) and astrocytoma (13.1\%) came second.

Conclusions: The incidence of childhood cancer in Iceland is similar to other Western countries. Long-term follow-up is very important in childhood cancer survivors.

Oskarsson T, Jonsson OG, Kristinsson JR, Jonmundsson GK, Jonasson JG, Haraldsson A

Childhood cancer in Iceland 1981-2006. Icel J Med 2010; 96: 21-26.

Key words: Childhood cancer, epidemiology, incidence.

Correspondence: Ásgeir Haraldsson, asgeir@landspitali.is

Barst: 30. júlí 2009, - sampykkt til birtingar: 16. nóvember 2009.

Galvus ${ }^{8} 50 \mathrm{mg}$ Stytt samantekt á eiginleikum lyfs

HEITI LYFS Galvus $50 \mathrm{mg}$ töflur. VIRK INNIHALDSEFNI OG STYRKLEIKAR Hver tafla inniheldur 50 mg vildagliptin. Ábendingar Vildagliptin er ætlað til meðferðar á sykursýki af tegund 2. Sem tveggja lyfja meðferð ásamt metformini, sulfonylurealyfi og thiazolidindioni hjá sjúklingum með ófullnægjandi blóðsykurstiórunun prátt fyrir meðferð. Skammtar og lyfjagjöf Pegar Galvus er notað í tveggia lyfja meðferð með metformini eða thiazolidindioni, er ráðlagður skammtur af vildagliptini $100 \mathrm{mg}$, gefið sem einn $50 \mathrm{mg}$ skammtur að morgni og einn 50 mg skammtur að kvöldi. Við notkun í tveggja lyfja meðferð með sulfonylurealyfi er ráðlagður skammtur af vildagliptini 50 mg einu sinni á sólarhring, að morgni. Hjá pessum sjúklingahópi hafði vildagliptin, $100 \mathrm{mg}$ á sólarhring, ekki meiri verkun en $50 \mathrm{mg}$ af vildagliptini einu sinni á sólarhring. Ekki er mælt með stærri skömmtum en $100 \mathrm{mg}$. Skert nýrnastarfsemi Ekki er börf á aðlögun skammta hjá sjúklingum með væga skerðingu á nýrnastarfsemi (kreatinin úthreinsun $\geq 50 \mathrm{ml} / \mathrm{mín}$.). Ekki er mælt með notkun Galvus hjá sjúklingum með í meðallagi skerta eða alvarlega skerta nýrnastarfsemi eða sjúklingum á blóðskilun með nýrnasjúkdóm á lokastigi. Skert lifrarstarfsemi Ekki má nota Galvus hjá sjúklingum með skerta lifrarstarfsemi, bar með talið sjúklingum með péttni alanin aminotransferasa (ALT) eða aspartat aminotransferasa (AST) > 3x eðlileg efri mörk fyrir meðferð. Aldraðir ( $\geq 65$ ára) Aðlögun skammta er ekki nauðsynleg hjá öldruðum sjúklingum. Reynsla hjá sjúklingum 75 ára og eldri er takmörkuð og gæa skal varúðar við meðferð hjá pessum hópi. Börn (<18 ára) Ekki er mælt með notkun Galvus fyrir börn og unglinga par sem engar upplýsingar liggja fyrir um öryggi og verkun. Frábendingar Ofnæmi fyrir virka efninu eða einhverju hjálparefnanna. Sérstök varnaðarorð og varúđarreglur við notkun Galvus kemur ekki í stað insúlíns hjá sjúklingum sem purfa insúlín. Galvus á ekki að nota hjá sjúklingum með sykursýki af tegund 1, eða til meðferðar á ketónblóðsýringu af völdum sykursýki. Skert nýrnastarfsemi: Takmörkuð reynsla er fyrir hendi hjá sjúklingum með í meðallagi skerta til alvarlega skerta nýrnastarfsemi og hjá sjúklingum með nýrnasjúkdóm á lokastigi sem eru í blóðskilun. Notkun Galvus er pví ekki ráðlögð hjá pessum sjúklingum. Skert lifrarstarfsemi: Ekki má nota Galvus hjá sjúklingum með skerta lifrarstarfsemi, par með talið sjúklingum með péttni ALT eða AST $>3 x$ eðlileg efri mörk fyrir meðferð. Eftirlit með lifrarensímum: Greint hefur verið frá mjög sjaldgæfum tilvikum um truflun á lifrarstarfsemi (par með talið lifrarbólgu). Í pessum tilvikum voru sjúklingarnir yfirleitt einkennalausir, án klínískra afleiðinga og niðurstöður úr rannsóknum á lifrarstarfsemi urðu aftur eðlilegar eftir að meðferð var hætt. Gera skal rannsóknir á lifrarstarfsemi áður en meðferð með Galvus er hafin til bess að finna grunngildi sjúklingsins. Hafa skal eftirlit með lifrarstarfsemi meðan á meðferð með Galvus stendur, á priggja mánaða fresti fyrsta árið og með reglulegu millibili eftir pað. Hjá sjúklingum sem hafa hækkuð transaminasagildi skal staðfesta niðurstöðurnar með pví að endurtaka rannsóknir á lifrarstarfsemi og eftir pað skal gera tíðar rannsóknir á lifrarstarfsemi par til gildin verða aftur innan eðlilegra marka. Ef hækkun á AST eða ALT sem nemur preföldum eðlilegum efri mörkum eða meira er viðvarandi, er mælt með pví að hætta meðferð með Galvus. Hjartabilun Reynsla af vildagliptin meðferð hjá sjúklingum með hjartabilun í New York Heart Association (NYHA) flokki I-II er takmörkuð og pví ætti að nota vildagliptin með varúð hjá bessum sjúklingum. Engin reynsla er af notkun vildagliptins í klínískum rannsóknum hjá sjúklingum í NYHA flokki III-IV og bví er ekki mælt með notkun pess hjá beim sjúklingum. Milliverkanir við önnur lyf og aðrar milliverkanir Vildagliptin hefur litla tilhneigingu til milliverkana við önnur lyf sem gefin eru samhliða. Par sem vildagliptin er ekki hvarfefni fyrir cýtókróm P (CYP) 450 ensímið og hindrar hvorki né hvetur CYP 450 ensím, er ekki líklegt að pað hafi milliverkanir við virk efni sem eru hvarfefni, hemlar eða hvatar pessara ensíma. Meðganga og brjóstagjöf Ekki liggja fyrir neinar fullnægjandi rannsóknaniðurstöður um notkun vildagliptins á meðgöngu. Par sem engar rannsóknaniðurstöður um menn eru fyrirliggjandi, er meðganga frábending við notkun Galvus. Galvus ætti ekki að nota meðan á brjóstagjöf stendur. Áhrif á hæfni til aksturs og notkunar véla Engar rannsóknir hafa verið gerðar til að kanna áhrif lyfsins á hæfni til aksturs eða notkunar véla. Aukaverkanir Algengar: Ógleði, skjálfti, höfðverkur,sund og preyta. Sjaldgæfar: Hægðartregða. Greint hefur verið frá mjög sjaldgæfum tilvikum um truflun á lifrarstarfsemi (bar með talið lifrarbólgu). Í bessum tilvikum voru sjúklingarnir yfirleitt einkennalausir, án klínískra afleiðinga og niðurstöður úr rannsóknum á lifrarstarfsemi urðu aftur eðlilegar eftir að meðferð var hætt. Mjög sjaldgæf tilfelli ofsabjúgs af vildagliptini hafa verið skráð af svipaðri tíðni og hjá samanburðarhópi. Handhafi markaðsleyfis: Novartis Europharm Limited, Wimblehurst Road, Horsham, West Sussex, RH12 5AB, Bretland. Umboðsaðilli á Íslandi: Vistor h.f. Hörgatúni 2, 210 Garðabær. Pakkningar og verð 1. ágúst 2008: Galvus töflur 50mg 30stk: 3.424kr. Galvus töflur 50mg 90 stk: 9.340kr. Afgreiðslumáti: R Greiðslupátttaka *Ath Textinn er styttur. Nánari upplýsingar um lyfið fást hjá Novartis, Vistor í síma 535-7000. 